\section{ÖN/GONDOSKODIK VAGY TOVÁBB DOLGOZIK?}

Kovács Erzsébet (tanszékvezetó egyetemi tanár, Budapesti Corvinus Egyetem, Operációkutatásés Aktuáriustudományok Tanszék

\section{ÖSSZEFOGLALÓ}

Az aktuáriusok idei világkongresszusán a hosszabbodó várható élettartam ténye és modellezése ${ }^{1}$, valamint az egyre fontosabbá váló nyugdijtudatosság voltak azok a hívószavak, amelyek köré számos előadó felfüzte mondanivalóját. A közgazdászok vándorgyülésén pedig panelbeszélgetést ${ }^{2}$ tartottak a biztosítási szakma vezetői, hogy jelenlétükkel is kiemeljék a hosszú távú öngondoskodási megtakarítások fontosságát. A budapesti nyugdíjszeminárium külföldi előadói a munka világában eltöltött évek meghosszabbítása, a rugalmas foglalkoztatás, a részleges nyugdíjazás mellett érveltek. Kicsit úgy hangzott ez, mintha az egyes nyugdíjpillérek növekvő szerepének korábbi hangsúlyozása helyett egy újabb „pillért”, a minél tovább tartó munkaviszonyt ajánlanák az érintettek és a szakemberek figyelmébe.

\section{SUMMARY}

This present article gives the summary of three conferences, which had the same topic in the center. The key speakers of the International Congress of Actuaries in this year focused on longevity and pension awareness. In the panel session of Regional Conference of Hungarian Economists the leaders of insurance industry discussed the importance of long term savings. The Budapest Pension Seminar was devoted to the flexible employment and partial retirement. Does it mean that extended employment is supposed to be the fourth pension pillar?

Kulcsszavak: várható élettartam emelkedése, nyugdíj, részleges nyugdíjazás Keywords: longevity, pension, partial retirement

\section{JEL: E21, H55, J14}

DOI: $10.18530 /$ BK.2018.4.72

http://dx.doi.org/1018530/BK.2018.4.72

\section{Bevezetés}

Milyen téma kötheti össze a világ aktuáriusainak 2018. évi berlini kongresszusát ${ }^{3}$, a Közgazdász Vándorgyülés pénzügyi szekciójának 2018. szeptember 7-én Debrecenben tartott ülését és a Budapesten 2018. szeptember 21-én tartott Pension Seminar programját? Az öngondoskodás az a fogalom, amely a különböző szakmai fókuszú találkozók középpontjába került ismét, és nem véletlenül.

A cikk célja kettős: összefoglalót adni az egyes rendezvényeken elhangzott főbb megállapításokról, másrészt összevetni a különböző szakmák képviselőinek helyzetértékelését.

\section{Debreceni üzenet: Mikor és milyen mértékben kell elkezdeni az öngondoskodást?}

Az események és felnőtt életünk időrendjében haladva tekintsük át először az aktív életkor kezdetén meghozható ideális döntést, a hosszú időhorizontú öngondoskodási termékek kiválasztását.

Kandrács Csaba, az MNB pénzügyi szervezetek felügyeletéért felelős ügyvezetôn igazgatója a közgazdászok számára ismert makroökonómiai összefüggések közé helyezve emelte ki az öngondoskodási termékek mint megtakarítási befektetések nemzetgazdasági szerepét. Rámutatott arra is, hogy a jól működő biztosítási és pénztári rendszerek mint intézményi befektetők kulcsszerepet játszanak mind az állam, mind a gazdaság - kiemelten a tőzsde - finanszírozásában, és megfelelő kiegészítést nyújtanak az egészség- és nyugdíjigények ellátására. A megtakarítási jellegből adódóan simítják a gazdaság ciklikusságát, hiszen konjunktúra időszakában a volumen növekedésével pénzt vonnak ki, hűtik a gazdaságot, míg a dekonjunktúra időszakában a felhalmozott vagyonok átcsatornázásával fütik a gazdaságot.

A bevezető gondolatok után 2016-os adatokkal alátámasztva emelte ki azt a tényt, hogy Magyarországon az öngondoskodást segítő termékek GDP-hez viszonyított aránya és a magyar háztartások vagyonán belüli megoszlása alacsonynak mondható az EU átlagához képest, ahogy ezt az 1. táblázat számai és az 1. ábra is megmutatják.

1. táblázat: Öngondoskodást segítő termékek (életbiztosítás, nyugdíjpénztár) hányada 2016-ban

\begin{tabular}{|l|c|c|}
\hline & GDP arányában \% & $\begin{array}{c}\text { Háztartási vagyon } \\
\text { arányában \% }\end{array}$ \\
\hline EU átlag & 52,4 & 18,3 \\
\hline Ausztria & 32,6 & 11,3 \\
\hline V3 & 14,4 & 8,9 \\
\hline Magyarország & 9,7 & 4,6 \\
\hline
\end{tabular}

Forrás: Eurostat 
Lemaradásunkat csökkentheti a 2017. évben végbement jelentős bérnövekedés, amelyről a 2018 elején megjelent MNB-kiadvány „A biztosítási szektor 10 éves jövőképe 7 pontban" ad képet. Ebben a kiadványban többek között megállapítják, hogy a háztartások által felhalmozott vagyon a GDP-nél jobban emelkedett.

\section{1. ábra: Az EU háztartásainak bruttó vagyona a GDP százalékában 2016-ban}

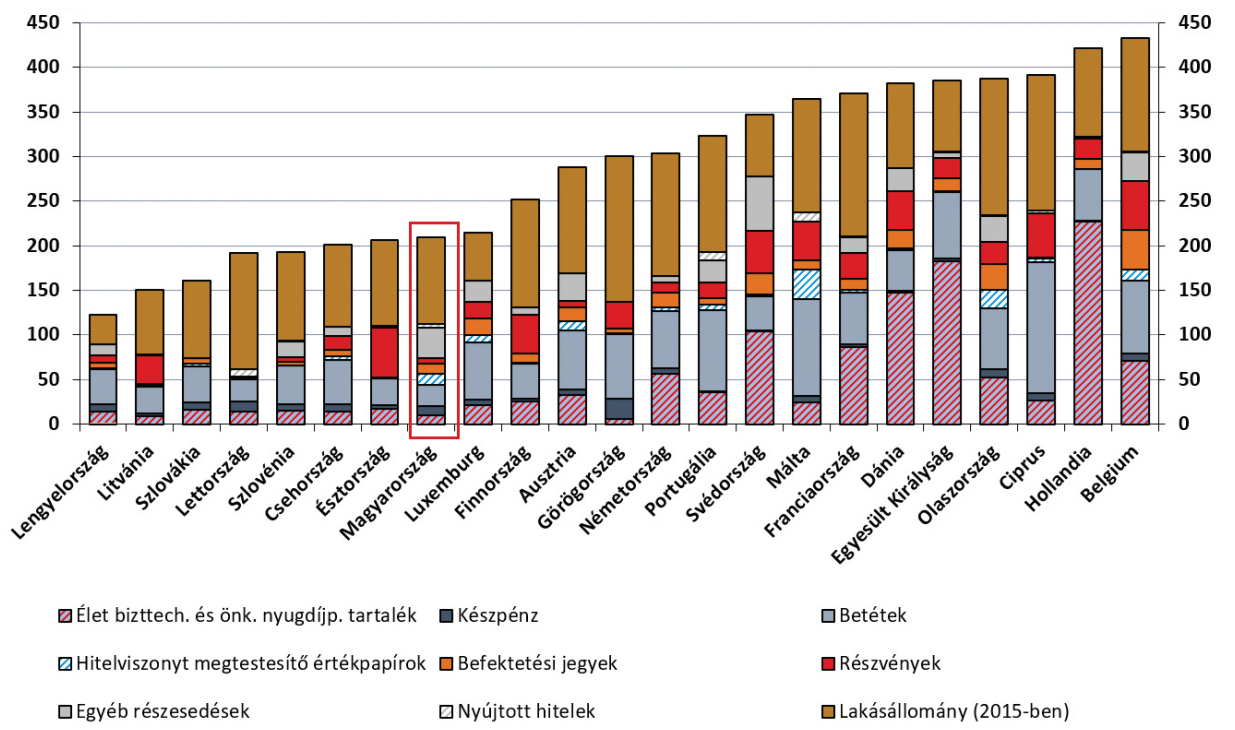

Forrás: „A biztositási, pénztári és tőkepiaci jelentés 2018, 2. ábrája”, Eurostat adatok

A panelbeszélgetésben öt vezető szakember vett részt, akik szakmai tapasztalatuk és tudásuk alapján a szerteágazó téma különböző aspektusaira világítottak rá:

- Erdős Mihály, elnök-vezérigazgató, Generali Biztosító Zrt.

- Hardy Ilona, alapító elnök, Aranykor Önkéntes Nyugdíjpénztár

- Horváth István, igazgató, a K\&H Bank Zrt. private banking igazgatóságának vezetöje

- Máté-Tóth István, vezérigazgató-helyettes, Budapesti Értéktőzsde Zrt.

- Pandurics Anett, elnök, Magyar Biztosítók Szövetsége, a Magyar Posta Biztosító Zrt. elnök-vezérigazgatója

A felkért beszélgetőtársak valamennyien a biztosítási és nyugdíj témák avatott szakértöi, de nem voltak könnyű helyzetben, amikor arra kellett válaszolniuk, hogy mi kellene ahhoz, hogy ne csak a háztartások által felhalmozott vagyon növekedjen a GDP-nél jobban, hanem az öngondoskodást segítő termékek aránya is?

Meggyőző válasz lehet a biztosítótársaságok és az önkéntes nyugdíjpénztárak képviselőitől az, hogy nincs ok az aggodalomra, hiszen a hosszú távú öngondosko- dást segítő termékek minden részletükben növekedést mutattak az utóbbi 5 évben, ahogy ezt a 2. táblázat számai is jelzik.

2. táblázat: A hosszú távú öngondoskodást segítő termékek megoszlása

\begin{tabular}{|l|r|r|r|r|r|}
\hline Mrd Ft & $\mathbf{2 0 1 3}$ & $\mathbf{2 0 1 4}$ & $\mathbf{2 0 1 5}$ & $\mathbf{2 0 1 6}$ & $\mathbf{2 0 1 7}$ \\
\hline $\begin{array}{l}\text { ÖNYP fedezeti } \\
\text { tartalék }\end{array}$ & 980 & 1081 & 1145 & 1246 & 1373 \\
\hline $\begin{array}{l}\text { Élet ági bizt. tech. } \\
\text { tartalék }\end{array}$ & 1648 & 1790 & 1840 & 1807 & 1830 \\
\hline NYESZ & 497 & 523 & 511 & 510 & 519 \\
\hline Összesen & 3125 & 3394 & 3496 & 3563 & 3722 \\
\hline Növekedés & & $109 \%$ & $103 \%$ & $102 \%$ & $104 \%$ \\
\hline
\end{tabular}

Forrás: $M N B$

De nem ilyen optimista a kép, ha a 2. táblázat összesen sorában az évről évre csökkenő növekedési dinamikát is látjuk, és ismét ránézünk az 1. ábrára, ahol csak Görögország és Litvánia ért el a magyar adatnál kisebbet, amikor az életbiztosítás technikai és az önkéntes nyugdíjpénztári tartalék összegét vizsgáljuk. A panel tagjai kiemelték, hogy az emberek többsége sajnálatosan 2-3 évet tekint hosszú távnak, túlságosan bíznak az állami nyugdíbban, és a reálbérek emelkedése, valamint az adókedvezmények fenntartása elengedhetetlenek az öngondoskodás ösztönzésében. Az Y generáció megszólításában látják a változás esélyét a biztosítótársaságok, hiszen ők bíznak legkevésbé a majdani állami nyugdíjban, és előttük áll mintegy 40-45 évnyi megtakarítási időszak, ami kellő pénzügyi tudatossággal párosulva nyugdíjas korra megfelelő megélhetést biztosíthat.

\section{Az Y generáció megszólításában látják a változás esélyét.}

Elgondolkodtató Kandrács Csaba azon felvetése is, hogy bár az életbiztosítók és önkéntes nyugdíjpénztárak kínálatában többféle portfólió is szerepel, a megtakarítók mégsem használják ki életkoruknak és ezáltal a lejárati időtávnak megfelelő kockázatú befektetési lehetőségeiket. Itt különbséget kell tennünk a klasszikus életbiztosítások és a modernebb termékek között. Hiszen az utóbbiak megvételével az egyének számára adott a magasabb kockázat vállalása, mivel a választható unit-linked eszközalapok szinte bármilyen kombinációját kérhetik. A magyar életbiztosítók és nyugdíjpénztárak azonban jellemzően fix összetételű portfóliót kínálnak. Aktívabb portfóliókezeléssel magasabb hozamokat lehetne elérni, ezzel a taglétszám növelése is elérhető lenne. Ugyanakkor a panel tagjai figyelmeztettek arra, hogy a magyar emberek jellemzően kockázatkerülőbbek, nem választanak részvényt. Összehasonlításul álljon itt a 3. és 4. táblázat, amelyek az európai és a magyar élet- és nyugdíjbefektetési arányokat mutatják. 
3. táblázat: Életbiztosítási portfólió összetétele 2016-ban

\begin{tabular}{|l|c|c|}
\hline Összetétel & EU átlag \% & Magyar adat \% \\
\hline Állampapír & 18 & 44 \\
\hline Befektetési jegy & 41 & 42 \\
\hline Részvény & 11 & 2 \\
\hline Vállalati kötvény és jelzáloglevél & 23 & 8 \\
\hline Készpénz és betét & 2 & 4 \\
\hline Egyéb & 4 & 0 \\
\hline
\end{tabular}

Forrás: $M N B$

4. táblázat: Önkéntes nyugdíjpénztári portfólió összetétele 2016-ban

\begin{tabular}{|l|c|c|}
\hline Összetétel & EU átlag \% & Magyar adat \% \\
\hline Állampapír & 31 & 57 \\
\hline Befektetési jegy & 5 & 27 \\
\hline Részvény & 32 & 5 \\
\hline Vállalati kötvény & 7 & 3 \\
\hline Egyéb kötvény és jelzáloglevél & $6^{*}$ & 4 \\
\hline Egyéb & 19 & 4 \\
\hline
\end{tabular}

Forrás: MNB (*: EU-átlagnál a kötvény jelzáloglevél nélkül 6\%)

A befektetési portfólió kiválasztása az egyéntől tudatosságot és pénzügyi ismereteket igényel. De az első döntés még fontosabb, hogy mikor kezdenek/kezdjenek el félretenni az emberek öngondoskodási céllal. Erre vonatkozóan az 5. táblázatban látható néhány egyéni szintű megtakarítási kalkuláció

\section{5. táblázat: A hosszú távra tervezett megtakarítások jellemzői}

\begin{tabular}{|l|c|c|c|}
\hline Jellemzök & \multicolumn{2}{|c|}{ önkéntes nyugdíjpénztár } & nyugdíjbiztosítás \\
\hline belépési életkor; év & 25 & 45 & 45 \\
\hline átlagos befizetés; Ft/hó & 7600 & 9500 & 17490 \\
\hline átlagbér arányában; \% & 2,6 & 3,2 & 5,9 \\
\hline megtakarítás; Ft & 5357000 & 2865000 & 5121072 \\
\hline induló havi járadék; Ft & 27138 & 14514 & 25864 \\
\hline nyugdíjkiegészítési ráta*; \% & 24,25 & 12,97 & 21,11 \\
\hline
\end{tabular}

Forrás: KSH, MNB, ONYF

${ }^{*}$ Nyugdijkiegészitési ráta = a nyugdijcélú megtakaritásból származó járadék aránya az átlagnyugdijhoz képest. Azátlagnyugdíj 111,9 ezer Ft/hó (Országos Nyugdíjbiztositási Főigazgatóság 2017. június havi adatai alapján).
A táblázat adatainak számítása során alkalmazott feltevések a következők voltak: a befektetéseken 2 százalék reálhozam érhető el, 20 százalék adójóváírás van érvényben, és 65 éves korban a még hátralévő várható élettartam: 16,5 év. Az első egyén 25 évesen lesz önkéntes nyugdíjpénztári tag, de havi jövedelméből keveset tesz félre. A második 45 évesen lép be, és bár többet tesz félre, fele annyi nyugdíjkiegészítést ér el. A harmadik személy is 45 éves, amikor nyugdíjbiztosítást köt, a 20 éves tartamon át befizetett nagyobb összeggel sem éri utol a 40 éves tartamon takarékoskodó első egyént.

Ami nem szerepel a táblázatban és a számításokban, az többek között a várható élettartam férfiak és nők közötti különbsége, valamint az a jövedelemeltérés, amely a nyugdíjpénztári tagok, de még inkább a nyugdíjbiztosítást vásárlók javára fennáll. Így e kettős hatás révén a biztosítottak a megtakarításaikat hosszabb időtávon élik fel, és a magasabb átlagjövedelmük miatti magasabb nyugdíjukhoz képest kisebb arányú lesz az így elérhető nyugdíjkiegészítés.

Az önkéntes nyugdíjpénztárak 2017-es tényadatai szerint a 60 év felettiek (60-65 évesek) számláján átlagosan 2,2 millió Ft van. Ebben az évben az átlagos szolgáltatáskifizetések két formában történtek:

- 1323 fö kapott járadékot, amelynek 1 före jutó havi átlagos mértéke 68000 Ft volt.

15388 fö pedig egy összegben vette fel az egy före jutó 1883000 Ft-nyi megtakarítását

A nyugdíjkiegészítés havi 68 ezer Ft-os mértéke túlzottan magas ezen 1323 fő esetében, feltételezhetően a pénztári vagyonuk is jóval átlag felett volt. Továbbá ne feledjük el azt sem, hogy ők az adott évben nyugdíjba vonulók 1,4 százalékát jelentik.

Vajon miért van az, hogy a döntő többség egy összegben vette fel a megtakarítását? Erről több szempontot is vizsgálva írt Ágoston Kolos a Biztosítás és Kockázat 2016. márciusi számában. Az egyéni bizonytalanság elsősorban abból fakad, hogy saját élettartamuk hosszában bizonytalanok, amikor arról kell döntést hozniuk, hogy a megtakarítást - nem túl magas összegü - járadékká váltva vegyék igénybe.

Az MNB „A biztosítási szektor 10 éves jövőképe 7 pontban” című kiadványában az életbiztosítók díjbevételére és a tartalékok alakulására is készített egy ideálisnak tartott pályamodellt. Ehhez hasonlóan az önkéntes nyugdijpénztári tartalékokra is készült egy projekció.

A hét pont közül az első a „Széles körü öngondoskodás”. A nemzetközi tapasztalatokat alapul véve az egy före jutó nyugdíjpénztári és életbiztosítási vagyonadatok alapján a következő 10 évre éves átlagos 7,8 százalékos növekedést vetítettek elöre. Így a 2016-os 8,7 százalék helyett 2026-ra az élet biztosítástechnikai és az önkéntes nyugdíjpénztár fedezeti tartalékok az optimista forgatókönyv szerint összesen elérhetik a GDP 10,1 százalékát.

Más elemzők, például Palkó István a Portfólióban arra mutatott rá, hogy 2015-ben 9,7 százalékot tett ki a háztartások életbiztosítási és nyugdíjpénztári megtakarítása a GDP arányában. A 2. ábra az arányok mellett azt is megmutatja, hogy ezzel az értékkel még a V3 (a többi visegrádi ország) átlagát sem érjük el. Az öngondoskodásra irányuló kiemelt figyelem tehát jogos és indokolt. 
2. ábra: A háztartások életbiztosítási és nyugdíjpénztári megtakarítása a GDP arányában

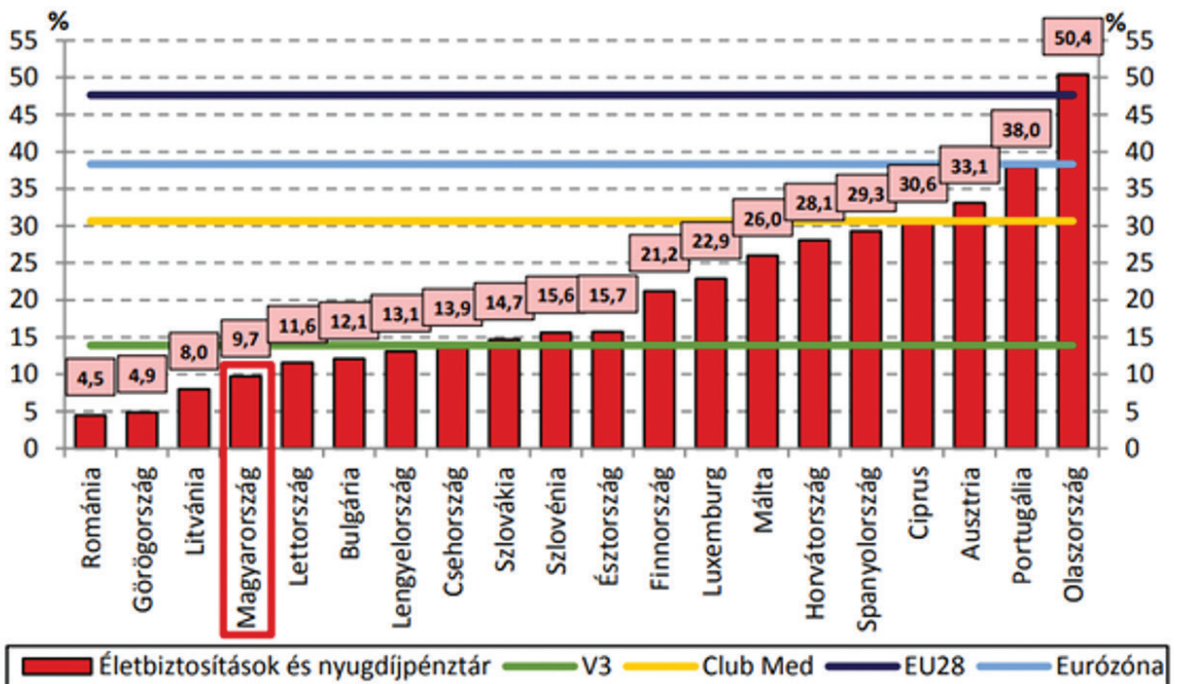

Forrás: Eurostat

Megjegyzés: V3, Club Med (Görörgország, Olaszország, Portugália és Spanyolország), EU28 és Eurózóna a tagországok számtani átlagát mutatja, Magyarország helyzetének láthatósága érdekében a magas skálát igénylö EU-országokat lehagytuk az ábráról.

\section{Budapesti üzenet: Öngondoskodás vagy hosszabb idő a munka világában?}

A Magyar Államkincstár idei Nemzetközi nyugdíjszemináriumának címe Work and pension - Phased and partial retirement volt. A központi téma a rugalmas nyugdíjrendszerek ismertetése, a részleges nyugdíjazás előnyeinek bemutatása volt. Nyolc külföldi szakértő vendég érkezett Budapestre erre a rendezvényre, és valamennyien amellett érveltek, hogy a munka világában eltöltött évek meghosszabbítása jelenthet megoldást arra a teherre, amely a nyugdíjrendszereket sújtja a hosszabbodó várható élettartam és a csökkenő gyermekvállalási kedv együttes hatásaként.

Az EU-tagállamok többsége az eddigi nyugdíjreformok során a nyugdíjrendszerek pénzügyi fenntarthatóságát javította. A reformintézkedések a legtöbb országban szigorították a korai nyugdíjba vonulást, és emelték a nyugdíjkorhatárt. De nem motiválták az egyéneket arra, hogy dolgozzanak tovább, megengedve a részleges munkaidőt, és résznyugdíjjal pótolva a munkaidő-csökkenés miatti jövedelemkiesést.

Témánk szempontjából kiemelten fontos volt ANDERSON Robert úrnak, az Eurofound-Social Policies Unit vezető munkatársának „Partial retirement in Europe” című előadása. Bemutatta, hogy a részleges nyugdíjba vonulás gondolata már korábban is felvetődött, és több országban nemzeti és ágazati szinten is elérhető ez a lehetőség, amint ezt a 6. táblázat is mutatja. Az ágazati szabályok a munkások nagy hányadát érintik, és kollektív szerződéseken alapulnak. A részleges nyugdíjba vonuláshoz is tartozhat minimum korhatár, ami például Finnországban 55 év.

6. táblázat: Nemzeti és ágazati szintủ résznyugdíjak országonként

\begin{tabular}{|c|c|c|c|}
\hline Ország & Nemzeti/ágazati & Szektor & $\begin{array}{l}\text { Bevezetés (kivezetés) } \\
\text { éve }\end{array}$ \\
\hline Ausztria & nemzeti & - & 2000,2016 \\
\hline Belgium & nemzeti & - & 1985 \\
\hline Csehország & nemzeti & - & 2010 \\
\hline \multirow{2}{*}{ Dánia } & nemzeti & - & 1986 \\
\hline & ágazati & $\begin{array}{l}\text { helyi kormányzat, } \\
\text { ipar, erdészet } \\
\text { közlekedés }\end{array}$ & $\begin{array}{l}2011,2012,2013, \\
2014\end{array}$ \\
\hline Finnország & nemzeti & - & $\begin{array}{l}1987 \text { közszféra } \\
1989 \text { magánszektor }\end{array}$ \\
\hline \multirow[t]{2}{*}{ Franciaország } & nemzeti & - & 1988 \\
\hline & ágazati & fém- és vegyipar & 2013,2014 \\
\hline \multirow[t]{2}{*}{ Németország } & nemzeti & & 1992,2004 \\
\hline & ágazati & $\begin{array}{l}\text { vegyipar, fém és } \\
\text { energetika Baden- } \\
\text { Württembergben } \\
\text { és közszféra }\end{array}$ & $\begin{array}{l}2008 \\
2008 \\
2010 \\
\end{array}$ \\
\hline Olaszország & nemzeti & - & 1996 \\
\hline Luxemburg & nemzeti & - & 1991 \\
\hline Hollandia & ágazati & $\begin{array}{l}\text { közszféra és } \\
\text { oktatás } \\
\text { egészségügy } \\
\text { fém- és mérnöki } \\
\text { média }\end{array}$ & $\begin{array}{l}1980 \\
2001 \\
2003 \\
2008\end{array}$ \\
\hline \multirow[t]{2}{*}{ Norvégia } & nemzeti & - & 1967 \\
\hline & ágazati & $\begin{array}{l}\text { közszféra és } \\
\text { magánszektor }\end{array}$ & $\begin{array}{l}1997 \\
1997\end{array}$ \\
\hline Lengyelország & nemzeti & - & 1998 \\
\hline Szlovénia & nemzeti & - & 2013 \\
\hline Spanyolország & nemzeti & - & 2013 \\
\hline \multirow[t]{2}{*}{ Svédország } & nemzeti & - & 1976 (2001), 2010 \\
\hline & ágazati & $\begin{array}{l}\text { kormány } \\
\text { helyi kormányzat } \\
\text { kétkezi dolgozók }\end{array}$ & $\begin{array}{l}2003 \\
2006 \\
2013\end{array}$ \\
\hline Nagy-Britannia & ágazati & $\begin{array}{l}\text { helyi kormányzat } \\
\text { egészségügy } \\
\text { felsőoktatás }\end{array}$ & $\begin{array}{l}2008 \\
2008 \\
2011\end{array}$ \\
\hline
\end{tabular}

Forrás: Eurofound, 2016. Extending working lives through flexible retirement schemes: Partial retirement 11-12. oldal 
Az Eurobarometer 2011-es kérdőíves felmérésében az egyik kérdés arra vonatkozott, hogy ha lehetősége lenne a teljes nyugdíj választása helyett résznyugdíjba vonulni, akkor élne-e ezzel a lehetőséggel. Az aktív korú megkérdezettek 65 százaléka igénybe venné a résznyugdíjat, 28 százalék nem, és 7 százalék nem tudott dönteni.

A nyugdíj-preferenciákat érintő hasonló vizsgálatot folytatott az Aegon ${ }^{4}$ 2014-ben. Hat országból ötben a kisebb hányad válaszolta azt, hogy azonnal és teljesen nyugdíba menne, ha elérte a nyugdíjkorhatárt. Ha lenne lehetőség részidőben dolgozni, akkor a britek 50 százaléka, a németek 46, a lengyelek 45 , a hollandok 43 és a magyarok 42 százaléka folytatná a „rugalmas” munkát, csak a spanyoloknál volt jóval alacsonyabb, 19 százalékos ez a szándék.

\section{】A magyarok 42 százaléka folytatná a „rugalmas” munkát.}

A rugalmas visszavonulási szándékok és a tények között nincsen szoros kapcsolat. 2012-ben készült az 55-69 évesek körében egy Eurofound felmérés arról, hogy van-e/volt-e lehetősége munkaidö-csökkentésre a nyugdíjhoz közeledő munkavállalónak. A 3. ábrán látható, hogy a hollandoknál ez tízszer akkora arányt jelent, mint a magyar vagy spanyol dolgozóknál.

3. ábra: A nyugdíj elött csökkentett munkaidőben foglalkoztatott 55-69 éves dolgozók aránya $\%$

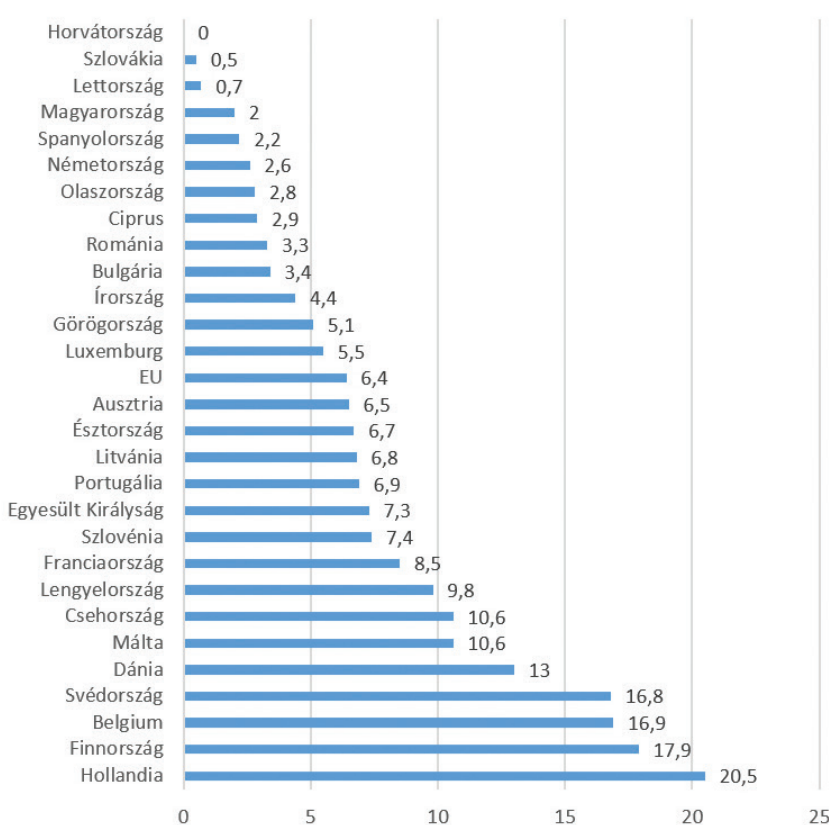

Forrás: Eurofound, 2016. Extending working lives through flexible retirement schemes: Partial retirement 21. oldal

\section{Összegzés}

A biztosítási és pénztári szektor szakemberei, valamint a várható élettartamot modellezők és elemzők, a nyugdij és öngondoskodás témát kutatók mind egyetértenek abban, hogy kevés az, ami eddig ezen a téren történt. Sem az egyének, sem a társadalom nem készült fel a várható élettartam további emelkedésére, a nyugdíban töltött évek anyagi biztonságának előzetes megteremtésére. Az egyéni megtakarításokhoz kapcsolódó tudatos kockázatvállalás a pénzügyi ismeretek további bővítését igényli. Ezen a téren van tennivalója mind az egyéneknek, mind a szektorban dolgozó pénzügyi tanácsadóknak. Az életpálya-tervezésben nyújtott felvilágosítás éppúgy része kell, hogy legyen a termék értékesítésének, mint ahogy elengedhetetlen a megtakarítások járadékra váltásával kapcsolatos ismeretátadás. A nyugdíjba vonulás tervezése nemcsak a társadalombiztosítási nyugdíj igénylését jelenti, hanem az élet- és nyugdíjbiztosítási termékek, a pénztári vagyon felélésének ütemezését is. Ezen pénz felhasználásának tervezését könnyíti meg a rugalmas nyugdíjba vonulás lehetősége, amit állami támogatás nélkül nehéz megvalósítani.

\section{Köszönetnyilvánítás}

A berlini konferenciarészvételt és a jelen tanulmányt az Európai Unió, Magyarország és az Európai Szociális Alap társfinanszírozása által biztosított forrásból az EFOP-3.6.2-16-201700017 azonosítójú „Fenntartható, intelligens és befogadó regionális és városi modellek” címü projekt finanszírozta.

\section{HIVATKOZÁSOK}

'Vékás Péter cikkét ajánlom a halandósági modellezés iránt érdeklődő olvasó figyelmébe. A cikk a Biztositás és Kockázat 2018. 3. számában jelent meg.

${ }^{2} A$ panelbeszélgetés és az itteni beszámoló alapjául dr. Kandrács Csaba, a pénzügyi szervezetek felügyeletéért felelös ügyvezetỏ igazgató (Magyar Nemzeti Bank) prezentácíója szolgált.

Hor

\section{IRODALOMJEGYZEK}

A biztositási szektor 10 éves jövơképe 7 pontban - Öngondoskodási kitekintéssel. https://www.mnb.hu/letoltes/biztosi-ta-si-szektorjo-vo-je-pst-online.pdf Letölttve: 2018. november 1.

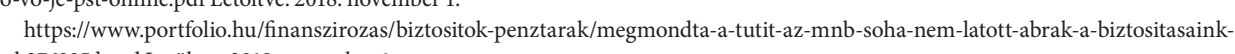
rol.276235.html Letöltve: 2018. november

Eurofound (2016): Extending working lives through flexible retirement schemes: Partial retirement. Publication Office of the European Kiston

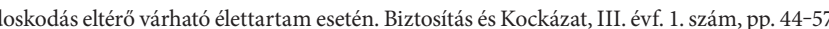

16): Felkészültünk a nyugdíira? Biztositás és Kockázat, III. évf. 3. szám, pp. 80-95.

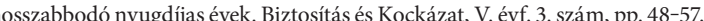

18530/BK.2018.3.48

作 http://dx.doi.org/1018530/BK.2018.3.34 